\title{
Francesco di Balduccio Pegolotit, and his Italianised Place NAMES: Allan Evans' Glossary of Pegolotit's place names of monasteries, priories, OR NUNNERIES IN ENGLAND, WALES, AND SCOTLAND
}

\author{
EPHRAIM NisSAN \\ London, England
}

\begin{abstract}
The Florentine merchant Francesco Pegolotti provided information about trade in his Pratica della mercatura, from the first half of the 14th century. Part of the charm of his book stems from how he Italianised place names, apart from its contribution to knowledge of Old Italian terminology, and to knowledge of real culture in the places and times covered. We delve into that material, beginning with how Pegolotti named places in England; these places had monasteries, something quite important in the economic system of the given period and given areas. We focus on the list of medieval religious houses (monasteries and nunneries) with which Allan Evans (1903-1970) in 1936 identified many Italianised place names from England, Scotland, and Wales, as found in Pegolotti's Pratica della mercatura. Keywords: Pratica della mercatura by Pegolotti; Italianised place names; monasteries in medieval England, Wales, and Scotland; English toponomastics.
\end{abstract}

\section{Introduction}

The Florentine well-travelled merchant Francesco Balducci Pegolotti (flourished 1310-1347), is important because of his Pratica della mercatura (compiled between 1335 and 1343):

Francesco Balducci Pegolotti (fl. 1310 - 1347), also Francesco di Balduccio, was a Florentine merchant and politician. His father, Balduccio Pegolotti, represented Florence in commercial negotiations with Siena in 1311. His brother, Rinieri di Balduccio, was suspected of connivance in the disappearance of a gold shipment in 1332 .

Francesco Pegolotti himself was a businessman in the service of the Compagnia dei Bardi, and in this capacity we find him at Antwerp from 1315 (or earlier) to 1317 . He was a director of the London office from 1317 to 1321, and is recorded (as Balduch) as having dealt directly with King Edward II. He was in Cyprus from 1324 to 1327, and again in 1335. In 1324 at Famagusta he negotiated a reduction of customs duties for the Compagnia dei Bardi and for those identified as Florentine merchants by the Bardi representative in the city. In 1335 he obtained from the King of Armenia a grant of privileges for Florentine trade. In 1331 and again in 1342 he was involved in Florentine politics as a Gonfalionere di Compagnia; in 1346 he held a higher position, Gonfalionere 
di Giustizia. In 1347, when the Compagnia dei Bardi collapsed, Pegolotti was among those who dealt with the consequences of the bankruptcy.

Between 1335 and 1343 he compiled the work for which he is famous, the Libro di divisamenti di paesi e di misuri di mercatanzie e daltre cose bisognevoli di sapere a mercatanti, commonly known as the Pratica della mercatura. Beginning with a glossary of Italian and foreign terms then in use in trade, the Pratica next describes nearly all the major trading cities then known to Italian merchants; the imports and exports of various regions; the business customs prevalent in each of those regions; and the comparative value of coinages, weights and measures.

The most distant trade route described by Pegolotti is that from Azov via Astrakhan, Khiva, Otrar and Kulja to Beijing. He also details the route from Ayas on the Cilician coast of Turkey via Sivas, Erzingan and Erzerum to Tabriz in Persia. ${ }^{1}$

In the rest of this study, we are going to refer to the 1936 edition of La pratica della mercatura, edited by Allan Evans and published by the Mediaeval Academy of America.

Pegolotti contributes to our knowledge of the terminology of Old Italian, and elsewhere I have made use of this in my research (Nissan and Burgaretta, submitted). Where Pegolotti was being resourceful and creative, however, was in his Italian adaptations of place names over a wide geographical area. Sometimes, he would have used a place name in a form also known to other Florentines. For example, he mentions fistuchi (pistachios) $)^{2}$ in a number of places, and one of those places is Bruges, his name for 2017).

1 https://en.wikipedia.org/wiki/Francesco_Balducci_Pegolotti (accessed in September

2 Standard Italian for 'pistachios' is pistacchi. Pegolotti however uses the form fistuchi. The latter word occurs fairly often in the Pratica della mercatura. In Sino-Iranica, Laufer (1919: 252, note 5) misspells Pegoletti: "Hence Pegoletti's fistuchi (Yule, Cathay, new ed. by Cordier, Vol. III, p. 167)" (citing Yule 1913-1916). This was a note to Ottoman Turkish fistiq. On that page, Laufer had listed, from various languages, names for 'pistachios': "The Persian word pista (also pasta) has been widely disseminated: we find it in Kurd fystiq, Armenian fesdux [where $x$ stands for kh] and fstoül, Arabic fistaq or fustaq, Osmanli fistiq, and Russian fistaška." As for Chinese, "It would not be impossible that the transcription pi-se-ta, accurately corresponding to Persian pista, was made in the Mongol period; for it bears the ear-marks of the Yüan [i.e., Mongol period] style of transcription."

The context of fistuchi in Pegolotti Pratica della mercatura is as follows, beginning with: "Fistuchi, e dàssi con esso il sacco e non se ne fa tara, salvo s'avessono più d'uno sacco per pondo sì si farebbe tara del piue, e l'uno rimane al comperatore per niente" (Pegolotti, ed. Evans, 1936: 24). Then in chapter 56, "Alessandria", Pegolotti enumerates staples sold in Alexandria by Egypt according to the different units of weight by which they are sold; of the weight units called qanțār, he lists three: "Cantare forfori, cantare gerui, cantare leuedi". Of these, most staples are sold by the cantar gerui ("A cantar gerui si vende"), and the word fistuchi appears there (Pegolotti, ed. Evans, 1936: 70). Chapter 64 is about Cyprus ("Cipri”). One finds there fistuchi enumerated among other staples (between sapone 'soap' and zibibbo 'sultana') under the rubric "A cantara di peso e a pregio di bisanti si vendono in Cipri” (Pegolotti, ed. Evans, 1936: 77). When he lists custom duty for various staples, he states: "Fistuchi, karati 12 per sacco" (Pegolotti, ed. 
it being Bruggia. ${ }^{3}$ We could expect this to have been a rather standard Italian form, but many other place names in the Pratica della mercatura occur there in forms he probably made up personally, for those forms to fit in his Italian text.

\section{Pegolotti and English place names associated with monasteries}

In his Pratica della mercatura, Francesco di Balduccio Pegolotti reports about trade in the eastern Mediterranean, Asia, between Anatolia and Beijing, and England, France and present-day Belgium, as well as ports in the Maghreb. The manner in which he Italianised toponyms, especially of places where there were monasteries in England, is bewildering.

In comparison, Latinised forms of place names as usual in the Middle Ages are somewhat easier to handle, but even so, there are confusing situations. The following is quoted from an entry in the glossary by Evans (Pegolotti, ed. Evans, 1936: 426):

Stanfortini:

Stamfords, 278.

Ducange offers two derivations of this name: Estanfordius and Stanfortis are cloths from 'borgo Stenfordia,' but Stamfortis is cloth made from stamen forte, i.e. of combed-wool yarn, the kind normally used for warp (Es, ii, 134). There is still no agreement on the subject; some authorities trace all forms of the name to the material, others to English

Evans, 1936: 86). In the chapter about Sicily ("Cicilia"), under the rubric "Mercatantia che si vendono a Messina a cantara sottile" one finds: "Fistuchi e fassi tara del sacco; galla e dàssi sacco per galla, e se tenesse terra o mondizia se ne farebbe tara" (Pegolotti, ed. Evans, 1936: 108). In the chapter about Venice ("Vinegia"), fistuchi is listed under the rubric "A centinaio si vende" (Pegolotti, ed. Evans, 1936: 138).

3 When dealing with Bruges, under the rubric "Quello che si paga senseraggio di mercantia e di cambio in Bruggia" about duties, Pegolotti states that fistuchi are included in the category of spices: "Gherofani e tutte spezierie sottile, denari 2 tornesi piccioli per libbra, e di denari 15 de' detti tornesi piccioli 1 grosso tornese d'argento. E in queste spezierie per erro fu messo zettoaro e fistuchi, e però in sul fare del mercato se puoi sì si vuol essere in accordo col curattiere del curattaggio di queste minute spezierie acciò che se puoi ne paghi meno, e se non sì ti converrebbe pagare lo 'ntero" (Pegolotti, ed. Evans, 1936: 243).

And indeed, Pegolotti's category "Spezierie" is broad, and in his chapter "SPEZIERIE cioè nomi di spezierie, e tutte quelle che averanno il punto di capo s'intende che sieno spezierie minute", being an alphabetised list of qualifying staples, Fistuchi is listed (Pegolotti, ed. Evans, 1936: 294). Notwithstanding such inclusion, the sense 'pistachios' is certain. The next two items are edible vegetables indeed: "Finocchi nostrali" ("our local fennels" and "Finocchi di Tunizi" ("Tunisian fennels").

In chapter 308, Pegolotti teaches how to evaluate quantities staple by staple, when unable to weight ("AVISAMENTO DI SAPERE COMPERARE E VENDERE SPEZIERIE A MISURA DI GRANO quando l'uomo si trovasse in parte ove non avesse o non potesse avere peso da potere pesare"): the unit of volume is the cafisso, and the equivalent weight is indicated for the particular staple. Concerning pistachios, we are told: "Il cafisso de' fistuchi pesa occhie 11" (Pegolotti, ed. Evans, 1936: 306). 
Stamford in Lincolnshire (Bo, i, $227 \mathrm{ff}$., compare Dc, 67). No one has noticed a third possibility in the fact that Stenfordium is actually the Latin form of Flemish Steenvoorde (Gr, 290), in French Estamfort (Es, ii, 486); nor is it allowed that there might here be two names of different origin. The name stanfortes appears as early as the 12th century, yet in that century these cloths were already being made at Arras and soon after at Ypres ( $\mathrm{Rm}, 840)$; in the early 13th century variations on the word are numerous: stamen forte, stanium forte, stanna fortis (Bo, i, $227 \mathrm{ff}$.); confusion is confounded by mention in 1265 of estani forti de Anglia, vel ... de Arraz (Ge, i, 254). It is hard, however, to escape the evidence recently brought forward by Reynolds, who found in his 12th century Genoese documents that far the larger part of the stanforts sold came from England, in $1197 £ 214$ worth as against $£ 35$ from Arras ( $\mathrm{Rm}, 846)$. Most likely, therefore, the name originated in England, perhaps not so much in the town of manufacture as at the Fairs through which the stuff passed into general trade (Dc, 67); it would soon have been copied on the continent and the name, used as an indication of quality (like Pirpignani, q.v.), would by popular etymology be related to the materials employed in manufacture. In any case, it was a cloth of high quality and value, much sought for the costume of court and aristocracy (Bo, i, $227 \mathrm{ff}$.).

The following is a key list for the abbreviations in the citations: Es = Espinas (1923), Bo = Bourquelot (1865), Dc = Davidsohn (1925), Gr = Graesse and Benedict (1922), Rm = Reynolds (1929), Ge = Germain (1861).

Pegolotti's book, as edited by Evans (1936: $392 \mathrm{ff}$.), includes Evans' "Glossary of English Religious Houses”. In its preamble, Evans wrote, among the other things (my added brackets):

These phonetic transcriptions of English names are sometimes hard to interpret; successive scribes who blindly copied the unfamiliar words have undoubtedly contributed to confuse the problem by distorting even further the original text. Fortunately some aid is at hand. Whether or not a Flemish list is the source of Pegolotti's text (see Introduction, p. xxviii), certainly Flemish adaptations of these same names have often proved to be illuminating guides for some of the authors mentioned above [i.e., in earlier research cited by Evans]. The fact that the items are arranged in roughly geographical order sometimes determines the area within which a given monastery must lie. If these resources fail, the text can often be made amenable by emendation, but this expedient has been used sparingly and only for errors which could with some safety be laid to scribal ignorance. Certain isolated and obvious changes have been corrected freely, also the easy and recurrent confusions of $n$ and $v$, or $u i$ and $i u, m$ and $i n$, always with a note to indicate the original reading. Elsewhere it is less certain that the anomaly may not be traced to Pegolotti's original work, and the temptation to emend has therefore been resisted.

In Pegolotti's book, Aberconway in Wales (where there was a Cistercian monastery) appears as Barcanoe in Gualesi (pronounced gwàlesi: - [w] used to become [gw $]$ in Tuscan). ${ }^{4}$ Evans indicated the modern county as being Denbighshire, which is in north-

4 Cf. Italian barca 'boat'. Was there deliberate attraction to that Italian noun? 
ern Wales. Abingdon in Berkshire, where there was a Benedictine monastery, appears as Ebindona. Egleston in Yorkshire (where there used to be a Premonstratensian monastery) appears as Agrestano. The latter name clearly displays attraction to the Italian adjective agreste or Latin agrestis, for 'agricultural', with an Italian suffix -ano which occurs sometimes in Italian place names. Alnwick in Northumberland appears as Alnuicche in Nortobellanda. The phonetic adaptation Alnuicche is rather pedestrian, whereas the omission of the $m$ and $r$ of Northumberland from the adaptation Nortobellanda deserves notice. Alvingham in Lincolnshire (where there was a Gilbertine monastery) appears as Alvingamo. Hampole in Yorkshire (where there was a Cistercian nunnery) was also known as Hanepole, and Evans points out that it is the latter English form that appears as Anipola in the Pratica della mercatura.

S.v. Ancordona, Evans remarks that there was a nunnery there, but he was uncertain whether to accept an earlier identification hypothesis with Ankerwyke in Buckinghamshire, where there was a Benedictine nunnery, or to rather opt (as "the context is so closely concerned with the north") for his own novel hypothesis of identification with Arthington in Yorkshire, where there used to be a Cluniacensian nunnery.

Evans then identifies Pegolotti's Ardena with Arden in Yorkshire, where there was a Benedictine nunnery. Evans identifies Pegolotti's Avenebi in Lendisia with Hagneby in Lindsey, in Lincolnshire, where there was a Premonstratensian monastery. Averolmo is Haverholme in Lincolnshire, where there was a Gilbertine monastery.

The next entry in Evans' list is quite interesting, as we find that Pegolotti adapted into Baleo in Essecchisi the place name Bileigh in Essex, where there was a Premonstratensian monastery. It is funny, surprising, but come to think of it, expected, that a medieval Florentine would adapt Essex into Essecchisi, with the first syllable stressed.

As for Balle di Rucco, Evans states that this is "[a] Scottish monastery which defies identification", and for which earlier scholars had suggested identification with Roxburgh. Evans also signals another hypothesis that had been made by another scholar: "As likely a guess would be Aberbrothock, sometimes spelled Aberbredock".

Pegolotti adapted the name of Bardney in Lincolnshire (where there was a Benedictine monastery) into Bardinaia. The latter form displays an Italian suffix which occurs in common names for places, as well as in proper names for places.

Evans identified Barmicciacche, as found in the Pratica della mercatura, as referring to a place called Balmerino now in the county of Fife in eastern Scotland; there used to be a Cistercian monastery there. Evans remarked: "Balmannac was an old variant of Balmerino; possibly the original read Barmunacche" (Pegolotti, ed. Evans, 1936: 392). That is to say, the reconstructed Tuscan form is one into which Pegolotti would have adapted Balmannac in a rather straightforward manner (note the interchange of liquid consonants, [1] and [r]); but then Pegolotti's spelling was miscopied, and the place name was corrupted into Barmicciacche.

Pegolotti's Basinguecche is identified with Basingwerk, in Flintshire in northeastern Wales. There used to be a Cistercian monastery there. Interestingly, Pegolotti adapted 
the name of Beigham in Sussex into Beccamo. It was the seat of a Premonstratensian monastery. There used to be a Cistercian monastery in Beaulieu in Hampshire, and whereas one could have expected Pegolotti to translate this literally into *Belluogo or *Belloco, the place name in the Pratica della mercatura which Evans identifies with Beaulieu is Bellaugolera: a modern Italian speaker would think of *bella úgola, 'beautiful uvula,' 'beautiful singing voice', with the addition of the suffix -era, suitable for common names denoting some place, and also for proper names referring to a particular place.

In contrast, Belvoir in Lincolnshire was the seat of a Benedictine monastery; in the Pratica della mercatura, it is called Bellvere - not the literal translation *Belvedere, which one could have expected. Incidentally, there is a forlorn place called Belvedere in south east London on the River Thames now, in the London borough of Bexley. It is the place of a remarkable Victorian piece of architecture from the 19th century, often likened to a cathedral. But it is a sewage pumping station. Whereas several volunteers have devoted time and effort to restore it to its past glory, and visitors come for sightseeing, Belvedere is the least desirable part of the borough of Bexley.

In Victorian England, in response to the Great Stink of the River Thames, London's sewerage system was designed and built under the direction of Sir Joseph Bazalgette, the Crossness Pumping Station was built in the Erith Marshes, now in South East London, in the present-day borough of Bexley. The centrepiece of the pumping station is a stunning octagon with colourful and intricately ornamented screens forming an octagon. It is sometimes likened to a cathedral. "The Crossness Works merely disposed of raw sewage into the river seawards, and in 1882, a Royal Commission recommended that the solid matter in the sewage should be separated out, and that only the liquid portion remaining should be allowed, as a temporary measure, to pass into the river. In 1891, sedimentation tanks were added to the works, and the sludge was carried by steam boats and dumped further out into the estuary, at sea".

Barlings in Lincolnshire, where there was a Premonstratensian monastery, is named as Berlinghe by Pegolotti. This is an adaptation that would have sounded apt for an Italian ear. By the way, the Berlinguer brothers, from Sardinia, were prominent Communist politicians in Italy in the 1970s and early 1980s. ${ }^{6}$ The pronunciation of their surname is berlingwèr.

Bittlesden, in Buckinghamshire, used to have a Cistercian monastery, and is mentioned in the Pratica della mercatura as Bettesdellana. The Italianised name differs because of metathesis, from the English name. Another Cistercian monastery existed in Blanchland, in Carmarthenshire in south Wales. The name as found in the Pratica

\footnotetext{
5 http://en.wikipedia.org/wiki/Crossness_Pumping_Station (accessed in September 2017).

6 In particular, Enrico Berlinguer (Sàssari, 1922 - Padua, 1984) headed, as secretary general, the Partito Comunista Italiano from 1972 to 1984. His brother was, at the time, in a sense, the party's top expert on all matters scientific, supposedly. They were cousins of the Christian Democrat politician Francesco Cossiga (a future president of the Republic), during whose tenure Aldo Moro was kidnapped and killed.
} 
della mercatura is Biancilanda. Note the replacement of [bl] with [by], which is typical of Tuscan and Italian in general. Evans remarked (Pegolotti, ed. Evans, 1936: 392): "Also known as Whitland; to be distinguished from the Premonstratensian Blanchland Abbey in Northumberland".

On p. 393 in Evans' edition of Pegolotti's Pratica della mercatura, further English place names are listed: Bielceffo is the Italianised form of the name Beauchief, of a Premonstratensian monastery in Derbyshire. It is interesting that Pegolotti did not translate literally as ${ }^{*} B e l c a p o$. (French and Old French beau and bel are variants of each other, for 'beautiful.) By rendering the component chief in the compound as ceffo, the semantics is changed: ceffo in Italian denotes 'muzzle', 'snout', and 'ugly or sinister face', as in the compound brutto ceffo 'ugly face.'

S.v. Biliguassi, Evans explains that this is Buildwas in Shropshire, the seat of a Cistercian monastery. "An old form of the name was Billewas" (Pegolotti, ed. Evans, 1936: 392). Again, we find [w] adapted into Tuscan as [gw]. Another Cistercian monastery is in Bindon, in Dorset, whose Italianised name in Pegolotti is Binendona (rather than *Bindona). Yet another monastery of that same order was in Byland, in Yorkshire. The Italianised form in Pegolotti is Biolanda.

Blida or Blyth in Nottinghamshire was the seat of a Benedictine monastery. Two Italianised forms appear in Pegolotti: Bria and Bliada. The text in the Pratica della mercatura states:

Bria, come viene della falda marchi 12 il sacco, ànnone da 6 sacca per anno.

Guirsapo presso a Bliada, come viene della falda marchi 12 sacco, ed ànnone da 5 sacca per anno.

Boxley in Kent (not the same a Bexley, now a suburb in South East London, but still part of Kent) used to be the seat of a Cistercian monastery. In Pegolotti, the Italianisation is delicious: Bocchesella in Chenti. Note that Chianti is a region in Tuscany. Bollintona is Bullington in Lincolnshire, and there was a Gilbertine monastery there. Bolton in Craven (in Yorkshire), where there were Austin Canons (Augustinians), is Boltrona in Cravenna in Pegolotti (rather than *Boltona).

In Oxfordshire, Bicester, near Brackley (itself in Northamptonshire), appears in Pegolotti as Borcecestri presso a Bracchelea. Evans remarks: "An alternative form was Burcester". This sits well indeed with the beginning of the Italianised form Borcecestri, which probably contains a diplography (a repetition of $c e$ ). In Bicester, there were Austin Canons.

Peterborough (in Northamptonshire) used to have a Benedictine monastery. There used to be the Latin form Burg Sancti Petri. Pegolotti translated literally into Italian, into Borgo San Pietro.

The name of the river Trent was rendered by Pegolotti as Tretta, by assimilation of the $n$. This is in "Bortona sor Tretta", referring to Burton on Trent in Staffordshire, where there was a Benedictine monastery. Brandinborno was identified by Evans as 
Bradbourne, in Derbyshire. Evans remarked: “A grange, 'grancia,' of Dunstable, situated in the Peak district. The monastery in 1205 received ecclesiam de Bradeburne, which lay near Esseburna, Ashbourne, Derby[shire]” (my brackets).

Balantrodoch Temple, in Edinburghshire in Scotland, is the referent of Pegolotti's Tenpo di Bratendocca. Interestingly, he did not render Temple by literal translation, with Tempio.

Brindellintona refers to Bridlington, in Yorkshire, where there were Austin Canons. Pegolotti's La Briuiera di Gontisgualdo refers to Bruerne in the Cotswolds, in Oxfordshire, where there was a Cistercian monastery. Evans remarks: "Closer to the Italian in the alternative form Brueria". There was a Cistercian monastery also in the place which for Pegolotti is Brondislea, but is Bordesley, in Worcestershire. Bourn in Lincolnshire, where there were Austin Canons, is Brono in Pegolotti. Bufeltro in Cornovaglia is how Pegolotti refers to Buckfastleigh in Cornwall, actually in Devon; there used to be a Cistercian monastery there, like also in what Pegolotti refers to as Calderea in Coppolanda, that is, Calder in Cumberland.

Evans felt unable to provide a referent for Pegolotti's Cansberi, and remarked: "Tewkesbury is suggested [by earlier scholars], and with a corrected form Tausberi would be a possible interpretation". Pegolotti's Catellea is Cattley, in Lincolnshire, the seat of a Gilbertine monastery. There also was a monastery of that same order in Chicksand in Bedfordshire, and Pegolotti calls that place Sisante. Pegolotti's Childirforte is Shelford, in Nottinghamshire; there were Austin Canons there. Pegolotti's Childomo is Keldholme, in Yorkshire, the seat of Cistercian nunnery.

Evans accepted an earlier scholar's identification of Pegolotti's Chilosola with Culross, in Perth county in Scotland, where there was a Cistercian monastery. Evans remarked that this identification "seems more reasonable than the distant Kinloss, Elgin" (i.e., Elginshire, renamed Moray, a county in northeastern Scotland). There was a Cistercian monastery in Kinloss. Evans pointed to the entry for Sansasano, which place he identified with St. Bathan's, in Berwickshire, the seat of Cistercian monastery. Then Evans remarked, in the latter entry: "unless Cunningham ${ }^{7}$ is right in suggesting St. Servan's, Culross".

Pegolotti's Chinchesulda was identified with Kingswood, in Wiltshire, the seat of a Cistercian monastery. Another monastery of that same order was in Pegolotti's Chinna, that is, Kinner in Merionethshire, in western Wales. S.v. Chirbebi, Evans identified the latter place name as referring to Monks Kirby, in Warwickshire, where there was a Benedictine monastery. Evans remarked: "Cunningham suggests the Austin Priory of Kirkby in Leicester [... ]. That house was founded in 1316, very near to the time when this list must have been compiled, and did not become a regular Austin Priory until $1359[\ldots]$. Why not the Benedictine Priory of Monks Kirby, even though no other alien priory is mentioned in this list $[\ldots]$ ?"

Whenever Evans cites Cunningham, the reference is to Growth of English Industry and Commerce during the Early and Middle Ages (5th ed., 1910) by William Cunningham (18491819), Archdeacon of Ely. 
The identification of Pegolotti's Chircamo is straightforward, with Kirkham, in Yorkshire, the seat of an Austin Priory. Chirchistallo in Ardona is Kirkstall in Arden, in Yorkshire, where there was a Cistercian monastery. Another monastery of that same order was in Kirksted, in Lincolnshire, and this is the referent of Pegolotti's place name Chiricchistede (presumably stressed on the first syllable). Chisiborno is, according to Evans, Gisburn or Guisborough, in Yorkshire, where there was an Austin Priory. Shap in Westmoreland, where there was a Premonstratensian monastery, is Ciappi in Vestrebellanda.

S.v. Cilesi in Condisgualdo, Evans provides an identification with Hayles in the Cotswolds, in Gloucestershire, where there was a Cistercian monastery. Evans remarked: "Possibly the text should be emended to read Eilesi". In the next entry, Evans identified Pegolotti's Clarerconi with Clattercote, in Oxfordshire, the seat of a Gilbertine monastery. Clementsthorpe, in Yorkshire, had a Benedictine nunnery; Evans identified it with Pegolotti's San Chimento. This is remarkable, as one would have rather expected ${ }^{*}$ San Clemente. Apparently Tuscan $[\mathrm{ky}]<[\mathrm{kl}]$ was at work here.

Pegolotti's Coccuelle is Goykwell, in Lincolnshire, where there was a Cistercian nunnery. Pegolotti's Conbo is Combe, in Warwickshire, which had a Cistercian monastery. Pegolotti's Conbrumera is Combermere, in Cheshire, where there was another Cistercian monastery. It is remarkable that Conchisala is how the Pratica della mercatura refers to Coggeshall, in Essex, where there was yet another monastery of that same order. Another remarkable Italianised name used in the Pratica della mercatura refers to a region: the name Condisqualdo refers to the Cotswolds (there was probably distortion by a copyist).

By Conte in Gualesi, Pegolotti referred to a place in Wales, but Evans could not tell which one. Evans remarked: "A Cistercian monastery. Conway is suggested [...] but I find no record of a religious house there". By Coverramo, Pegolotti referred to Coverham, in Yorkshire, where there was a Premonstratensian monastery.

Croxden in Staffordshire, where there was a Cistercian monastery, is Pegolotti's Crocchestrende (note the insertion of an $[\mathrm{r}]$ ). Pegolotti's Croncestona is, Evans claimed, Croxton in Leicestershire, which had a Premonstratensian monastery. Evans remarked: "Cunningham's transcription read Crocenstona, and there is some doubt as to how the abbreviation, a line superscript from $o$ to $s$, should be resolved". Pegolotti's Crolanda is Crowland, in Lincolnshire, where there was a Benedictine monastery.

It is interesting that Canterbury, in Kent, the seat of a Benedictine monastery, appears in the Pratica della mercatura as Cuntorberi (instead of ${ }^{*}$ Cantorberi. Cf. French Cantorbéry). Evans identified Pegolotti's Cupero with Cupar Angus, in the county of Perth in Scotland, where there was a Cistercian monastery. Pegolotti's La Dalla is Dale, in Derbyshire, which had a Premonstratensian monastery. Pegolotti's Dereforte is Dureford, in Sussex, where there was another monastery of that same order. Pegolotti's Derlea is Darley, in Derbyshire, where there were Austin Canons.

S.v. Diepinghe, Evans provided an identification with Deeping, in Lincolnshire, where there was a Benedictine monastery. Evans remarked: "Cell to Thorney Abbey. In the Ms. the name is written Diepiaghe, a not uncommon confusion of $a$ and $n$ ". 
On p. 394, Evans continued: Pegolotti's Diolaccresca is Dieulacres, in Staffordshire, there being a Cistercian monastery there. The Old French name (literally meaning "Let God make it increase") was translated literally into Italian by Pegolotti. He referred by the Italianised name Dondarnane to Dundrennan, in Kirkcudbright, a county in south west Scotland. There was a Cistercian monastery there. Another place in Scotland was referred to by the aesthetically pleasing Italianised name Donfermellino, that is, Dunfermline, in county Fife, where there was a Benedictine monastery. There was an Austin Priory in Dunstable, in Bedfordshire, whose name was adapted by Pegolotti as Donnistabile.

Pegolotti's Dora is Dore, in Herefordshire, which had a Cistercian monastery. There were Austin Canons at Drax in Yorkshire, and Pegolotti referred to the place by the Italianised form Dradicchisi (was that a distortion of Dracchisi, stressed on the first syllable?). Another Austin Priory was at Trentham in Staffordshire, which in the Pratica della mercatura is referred to as Dreccheno. Elertana is Ellerton, in Yorkshire, where there was a Gilbertine monastery.

Elmetta in Yorkshire is Pegolotti's Elmetta. Evans remarked:

A monastery is heard of in Elmet about 730 [... ], but apparently not after that time, and the name is here listed in reference to the district as a source of 'collected wools,' perhaps even as representative of the West Riding (see Ledesia). The parish names Sherburn-inElmet and Barwick-in-Elmet place the region immediately to the east and northeast of Leeds $[\ldots]$

Pegolotti's Endicamo is Yedingham, in Yorkshire, where there was a Benedictine nunnery. Pegolotti's Eninghe was the town of Hevening (from the form Heyninges), in Lincolnshire, where there was a Cistercian nunnery. By Evesamo in Condisgualdo, the Pratica della mercatura refers to Evesham in the Cotswolds, in Worcestershire. There was a Benedictine monastery there.

S.v. Finevete, Evans provided an identification with Fineshed, in Northumberland, where there was an Austin Priory. Evans remarked: "This identification is confirmed by the added hint that the monastery lies 'a 5 miglia presso a Stanforte'". Next, Evans identified Pegolotti's Fontana with Fountains, in Yorkshire, where there was a Cistercian monastery.

Fordamo in Sulfolco is how Pegolotti referred to Fordham in Suffolk, in Cambridgeshire, where there was a Gilbertine monastery. Pegolotti's Forde is Ford, in Devon, the seat of a Cistercian monastery. Another monastery of that some order was found in a place that Pegolotti names Fornace in Nortobellanda, that is, Furness in Northumberland, in Lancashire. Yet another monastery of that order was found in Flexley in Gloucestershire, and in the Pratica della mercatura that place is called Fraschelea.

In Scottish onomastics, Kelso is a place name and a surname. There was a Benedictine monastery in Kelso, in Roxburgh, a county in southern Scotland. It is remarkable that Pegolotti achieved the Italian-sounding adaptation Ghelzo. 
Pegolotti's Gierondona is Garendon, in Leicestershire. There was a Cistercian monastery there. Another such monastery was in Jervaulx, in Yorkshire, and Pegolotti adapted the name as Giervalese. There was a Benedictine monastery in Wittering, in Northamptonshire. That place is identified with Gitterono in the Pratica della mercatura.

Evans was in doubt whether Pegolotti's Granno was Grantham. He remarked: "A district for 'collected wools.' In the Ms. the second $n$ is blotted and the word might be, as Pagnini printed it, Gramo, hence, it is faintly possible, Carham-up-Tweed [... ]. It is most likely, however, that Grantham is here listed to represent wools from the Parts of Kesteven (see Ledesia)".

We come across literal translation on the part of Pegolotti, when he uses La Graziadio in order to refer to Grace Dieu, a Cistercian monastery in Monmouthshire in Wales. Pegolotti's Grenellusso is Glenluce, in the county of Wigtown in south western Scotland. There was a Cistercian monastery there.

Evans was uncertain as for the referent of Pegolotti's adapted name Gridegorda: Evans wondered whether it was Jedburgh, in the county of Roxburgh in southern Scotland. There was an Austin Priory there. Evans remarked: "Dryburgh has been suggested $[\ldots]$, but Jedburgh, particularly in the early form, Jeddeworth, seems closer to the Italian”. Why the initial Gri...?

Pegolotti referred to the town of Grimsby in Lincolnshire, where there was a Benedictine nunnery, by the adapted name Grimes $b i$, stressed on the first syllable, and with an interpolated vowel (breaking the consonantal cluster). There also was Grimesbi in Lendisia, which Evans identified as "Wellow or Grimsby in Lindsey", in Lincolnshire, where there was an Austin Priory.

Gualtamo is how Pegolotti refers to Waltham, in Essex, where there was another Austin Priory. Note the Tuscan replacement of $[\mathrm{w}]$ with $[\mathrm{gw}]$. There is the remarkable adaptation Guantona (as though it means 'big glove' in Italian), referring to Watton in Yorkshire, where there was a Gilbertine monastery. Evans remarked: "Watton rather than Walton". Wardon in Bedfordshire, where there was a Cistercian monastery, is for Pegolotti Guardona. It is semantically remotivated (apparently not far from the perceived literal sense of the English place name) as a place where one either stands guard, or a place that itself stands guard, or where one can watch the landscape.

Warter in Yorkshire, where there was an Austin Priory, was Pegolotti's Guarterra. Waverley in Surrey, where there was a Cistercian monastery, is called Guarverlea in the Pratica della mercatura. There was a Benedictine monastery in Winchcombe, in Gloucestershire, and in the Pratica della mercatura it is referred to by the name Guicciconbo. There was an Austin Priory in Worksop, in Nottinghamshire, and Pegolotti refers to that place by the name Guirsapo (presumably stressed on the first syllable).

S.v. Guitebi Ostrattone, Evans identified the place as Whitby, in Yorkshire, where there was a Benedictine monastery. Evans remarked: "The meaning of ostrattone is unknown, unless it bears some relation to the name of the district or wapentake Whitby Strand, see T. Allen, History of the County of York, vi (London, 1831), 207”. There was 
another Benedictine monastery in Coldingham, in Berwickshire, and in the Pratica della mercatura it is referred to by the name Guldingamo.

Hilton in Staffordshire (the seat of a Cistercian monastery) is Pegolotti's Iltona. By Lagalea in Sifolco (not writing down the nasal $n$ ), Pegolotti referred to Langley in Suffolk, in East Anglia (in modern times it is part of Norfolk, not Suffolk). There used to be a Premonstratensian monastery in that place. By La Landa, Pegolotti referred to Launde, in Leicestershire, where there was an Austin Priory. Langley in Leicestershire, where there was a Benedictine nunnery, is Pegolotti's Langalea. His Lantarname is Llantarnam, in Monmouthshire in Wales, the seat of a Cistercian monastery.

The place name Lanualderia, in the Pratica della mercatura, occurs in "Lanualderia, torcia marchi 11 il sacco, ed ànnone da 6 sacca per anno". S.v., Evans did not decide about any identification. Evans remarked: "Cunningham emends to read Lavualderia and suggests Welbeck, [in Nottinghamshire, where there was a Premonstratensian monastery], which seems remote unless the word is further emended to some form such as La Valbekia".

Pegolotti's Leccheborno is Legbourne, in Lincolnshire. It had a Cistercian nunnery. Concerning Pegolotti's place name Ledesia, Evans wrote (Pegolotti, ed. Evans, 1936: 394-395):

This might be the Austin Priory of Leeds, Kent, but the items of the small list in which this name occurs are all districts which produce 'collected wools'; the price is high for a southern wool, and the district in Lincolnshire is here preferred. The town of Leeds, Yorks[shire], is possible ( $\mathrm{Cu}$ [nningham 1910], 630), but would involve duplication with Elmet (see Elmetta). If this interpretation is accepted, it will be noticed that each of the three divisions of Lincolnshire is represented in the list of 'collected wools', the Parts of Kesteven by Grantham, Holland by Holland Brigg (see Granno and Ponte); similarly the three Ridings of Yorkshire may be represented by Thirsk, Elmet, and, if it be allowed, York (see Tresche, Elmetta, Vervicche). The appropriateness of this scheme serves in itself to corroborate the identifications.

By Lentona in costa a Nontingamo, Pegolotti referred to Lenton near Nottingham, where there was a Cistercian nunnery. Note that instead of adapting Nottingham into ${ }^{*}$ Nottingamo, the $t$ is preceded by a perhaps nasal $n$ in Nontingamo.

Pegolotti's Letteleccia was identified by Evans with Letley in Hampshire, which had a Cistercian monastery. Evans also proposed alternatives: "Otherwise Netley or Edwardstow". Evans felt unable to identify, in the Pratica della mercatura, Lofusteltro in Gondisgualdo; Evans remarked: "Cunningham [(1910: 640)] emends to read Lofusfeltro and suggests Luffield in the Cotswolds", in Northumberland, where there was a Benedictine monastery. Another identification hypothesis was with Gloucester.

Pegolotti's Luia and Parco di Luia were identified by Evans with Louth Park, in Lincolnshire, where there was a Cistercian monastery. Evans identified Pegolotti's Luizenstri with Leicester, and noted that the region was referred to "as a source of 'collected wools'”. 
Evans was unable to identify Magione Reale, which suggests a royal palace. Pegolotti's Maltona is Old Malton, in Yorkshire. There was a Gilbertine monastery there. Pegolotti's Maricche is Marrick, again in Yorkshire. It has a Benedictine nunnery. There was a Gilbertine monastery also in Mattersey, in Nottinghamshire. That place was also known as Marsey, and in Latin ecclesia de Marseia, so this is the identification of Pegolotti's Marisea.

Marchebi in Lendisie is how Pegolotti refers to Markby in Lindsey, in Lincolnshire. It had an Austin Priory. There was another such priory in Merton, in Surrey, and Pegolotti referred to the place by the name Martona. Pegolotti also mentions a place he names Mieldona, but Evans was unable to identify it, and rejected an earlier hypothesis. Evans remarked: "There was a Carmelite House at Maldon, Essex, but no others of this Order are named in the list".

Miesa in Oldarnese is how Pegolotti refers to Meaux in Holderness, in Yorkshire. There was a Cistercian monastery. Note that in the adaptation Oldarnese, the Italian suffix is made to stand for the unrelated ending of the English name Holderness. At one point, Pegolotti refers to a place he calls Miramando. This is Mirmaud (also known as Marmond) in Cambridgeshire. There was a Gilbertine monastery. Incidentally, in Lombardy there is the abbey of Morimondo, originally Miramondo. Miramondo means 'watch the world', whereas morimondo means 'die, world', or rather 'die to the world': joining the abbey was taken to require abandoning mundane links to society.

By Miravalle ('watch the valley'), Pegolotti referred to the Cistercian monastery of Merevale, in Warwickshire. This is an example of literal translation from Old French. Pegolotti's Mirososso was identified by Evans with the Cistercian monastery of Melrose, in the county of Roxburgh in southern Scotland.

It is remarkable that Pegolotti's Monacherone, a name that appears to have been remade in Italian, by semantic motivation from monaco 'monk', was identified with Nunmonkton in Yorkshire, the place of a Benedictine nunnery. Take note of how Nunmonkton lends itself to be analysed from nun and monk.

The name Montingamo in the Pratica della mercatura was identified by Evans with Nottingham; he remarked: "The region as a source of 'collected wool'. Pegolotti's Morgana is Margam Abbey, a Cistercian monastery in Glamorganshire in southeastern Wales. Evans remarked: "A variant of the name is Margan, and even, in the 16th century, Morgan". There also was a Cistercian monastery in Neath, in Glamorganshire. Neath is called Nietta by Pegolotti.

It is interesting that Newbottle in Edinburghshire, in Scotland, where there was a Cistercian monastery, is called Niobottoli by Pegolotti. By Nio Mostriere in Nortobellanda, he referred to Newminster in Northumberland, also the place of a Cistercian monastery. Pegolotti's Niuborgo is Newburgh, in Yorkshire, where there was an Austin Priory. Pegolotti's Niuinamo is Newnham, in Devon, where there was yet another Cistercian monastery.

Evans identified Pegolotti's Niusumi with Newsome or Newhouse, in Lincolnshire, the place of a Premonstratensian monastery. There was an Austin Priory at Nocton 
Park in Lincolnshire; in the Pratica della mercatura, that place is called Noccona Parco. Pegolotti's Nonocotono is Nuncoton, in Lincolnshire, where there was a Cistercian nunnery.

S.v. Norbonucche, Evans tentatively suggested an identification with North Berwick, where there was a Benedictine nunnery. Evans identifies Nostra Dama di Liuzestri with St. Mary de Pré in Leicester, an Austin Priory. As for Nostra Dama di Vervicche, Evans identifies it with St. Mary's Abbey in York (not in Warwick!), a Benedictine monastery.

Nottolea is how Pegolotti refers to Nutley, in Buckinghamshire, the place of an Austin Priory. There is literal translation in the place name Novelluogo in Scireuda, that is, Newstead in Sherwood, in Nottinghamshire. There were Austin Canons there, too. There was a Gilbertine monastery in Newstead in Lincolnshire, a place Pegolotti calls Novelluogo (by literal translation).

Pegolotti's Olcoltramo is Holm Cultram, in Cumberland; there was a Cistercian monastery. Olesamo in Lendesie is how Pegolotti refers to Ailesham in Lindsey, in Lincolnshire, where there was an Austin Priory. By Onbrestano in Lendisie he referred to Humberston, in Lincolnshire, the place of a Benedictine monastery. Pegolotti's Ormesbi is Ormsby Priory, a Gilbertine house in Lincolnshire.

By Osnea in Condisgualdo, Pegolotti was referring to Osney, in Oxfordshire, the place of an Austin Priory. By the name Condisgualdo, Pegolotti was referring to the Cotswolds. The name Ottubo from the Pratica della mercatura was identified by Evans with Neuboth, in Lincolnshire, where there was a Premonstratensian monastery.

Il Pecche is how Pegolotti referred to The Peak, a district in northern Derbyshire. It is interesting that he did not Italianised into Il Picco. Rocester (sic) is a town in Staffordshire. In the Pratica della mercatura, Rovincestri in costa al Pecche stands for Rocester near the Peak. There was an Austin Priory there.

Pershore in Worcestershire, the place of a Benedictine monastery, was called by Pegolotti Persore. He adapted the name of Pipewell in Northamptonshire (where there was a Cistercian monastery) into the form Pippuelle. Besides, Ponte in Italian denotes 'bridge'. It is how Pegolotti refers to Holland Brigg, in Lincolnshire, where there was a Gilbertine monastery. Evans remarked:

In the Ms. Dinponte, the name has always been a puzzle. Huntington was suggested [...] But there are many examples of an $n$ being interpolated, and Di Ponte at once suggests that this is a listing of the 'collected wools' of Holland Brigg or of the Parts of Holland (see Ledesia), apart from the product of the Priory itself as listed under the following item of this index.

On p. 396, Evans continued: Pegolotti's Ponte Ruberto is Robertsbridge, in Sussex, where there was a Cistercian monastery. It is somewhat surprising that the Pratica della mercatura refers to the Quarrer on the Isle of Wight by the name La Quarriera dell' Isola di Gucco (it was the place of a Cistercian monastery). Pegolotti's Ramisea is Ramsey, 
in Huntingdonshire in central England. It has a Benedictine monastery. Pegolotti's Renpendona was identified by Evans with Repington or Repton, in Derbyshire, where there was an Austin Priory. Pegolotti's Revesbi is Revesby, in Lincolnshire, the place of a Cistercian monastery.

By an interesting Italianisation, Pegolotti used the name Ricciamonte in order to refer to St. Martin Richmond, in Yorkshire. It was a Benedictine monastery. Rivalse (which in Italian can be interpreted as 'revanches') is how Pegolotti referred to Rievaulx, in Yorkshire, a Cistercian monastery. Roccea and Roccia are names used by Pegolotti for Roche, in Yorkshire, where there was another Cistercian monastery. Pegolotti's Rosedalla is Rosedale, in Yorkshire, a Benedictine nunnery.

It is funny that Rutland, a region producing wool, was called Rottolando in Italian by Pegolotti. In Italian, the verbal form rotolando denotes 'by rolling', or, more aptly for wool, 'by rolling up'. By Rufforte in Esciereuda, the Pratica della mercatura refers to Rufford in Sherwood, in Nottinghamshire, where there was a Cistercian monastery. Pegolotti's Sallebi is Sulby, in Northumberland, the place of a Premonstratensian monastery. By Salleo in Cravenna, Pegolotti referred to Salley in Craven, in Yorkshire, where there was a Cistercian monastery. Pegolotti's Salterrea is Sawtry, in Huntingdonshire, the place of another such monastery.

By Santa Agata, Pegolotti referred to Easby, the seat of the Abbey of St. Agatha, in Yorkshire. It was a Premonstratensian monastery. By Santa Caterina di Niccola, Pegolotti referred to the Gilbertine monastery of St. Catherine in Lincoln. Note the distortion of Lincoln into Niccola.

By Santa Indigonda, St. Radegund's Abbey is referred to in the Pratica della mercatura. It was a Premonstratensian monastery in Bradsole, in Kent. By Santo Andrea di Norettona, Pegolotti referred to St. Andrew's, a Cistercian nunnery in Northampton. It is remarkable that the Gilbertine monastery of St. Andrew's, in York, is referred to in the Pratica della mercatura as Santo Andrea di Verrvicche, according to Evans, s.v. One would have expected the Italianised city name to refer to Warwick instead.

Evans was in doubt as for the referent of Santo Nogli Borgo Sestri (cf. the town of Sestri in Liguria). Evans remarked: "Possibly St. Ossyth near Colchester or St. Botolph in the same town". Evans identified Pegolotti's Santo Usgualdo with the Austin (Augustinian) Priory of St. Oswald, in Nostell, in Yorkshire.

Saperingamo is Sempringham, in Lincolnshire. It was the seat of a Gilbertine monastery. Pegolotti's Scippitona is Sibton, in Suffolk. There was a Cistercian monastery there. Selby in Yorkshire, where there was a Benedictine monastery, is Pegolotti's Sellebi (the stress on Sellebi must have been on the first syllable).

Sicchisille is Pegolotti's Italian adaptation of the name of Sixhill, in Lincolnshire, where there was a Gilbertine monastery. Pegolitti's Soldamo is Shouldham, in Norfolk, the place of another such monastery. Pegolotti's Spaldinghe is Spalding, in Lincolnshire; it had a Benedictine monastery.

Stallea in Gildisire is identified with Stanlegh in Wiltshire, where there was a Cistercian monastery. Stalleo in Guaruicche is identified with Stoneleigh in Warwick, 
where there was a monastery of that same order. Stalleo in Zestri refers to Stanlaw in Cheshire, where there was yet another Cistercian monastery.

Pegolotti's Stanfeltro is taken to be Stanfield, in Lincolnshire. It has a Benedictine nunnery. Evans felt unable to identify Pegolotti's Stanforte in a particular context, but he remarked about earlier hypotheses: "Strata Marcella, Montgomery, is suggested [...]; also Strata Florida [...]. Might this not be the Stafford house of another Order, for instance the Austin Priory of St. Thomas, which has strayed into the Cistercian group on this list?" Another occurrence, in the Pratica della mercatura, of the name Stanforte was identified by Evans with Stratford in Essex, where there was a Cistercian monastery. Evans remarked: "This occurrence of the name is so translated because the context is concerned with Essex and the East".

Pegolotti's Sticchisigualdo is Stixwold, in Lincolnshire, where there was a Cistercian nunnery. Another Cistercian nunnery was in Swinhey in Yorkshire, and Pegolotti called it Suino (Italian for 'swine'). There was a Cistercian monastery in Swineshed, in Lincolnshire, and surprisingly and funnily, in the Pratica della mercatura that place is called Suinsivede (which in Italian can be interpreted as 'swine is seen'). Evans remarked: "More easily identified under the older form Swynesheved".

Pegolotti's Tamo is Thame, in Oxfordshire, the place of a Cistercian monastery. Pegolotti's Tanterna is Tintern, in Monmouthshire in Wales. It was the place of another monastery of that same order. In the Pratica della mercatura, the name Ticcifeltro appears, and Evans identified it with Tichfield, in Hampshire, where there was a Premonstratensian monastery.

Tilitea is how Pegolotti refers to Tiltey, in Essex, the place of a Cistercian monastery. In the Pratica della mercatura, the name Tinecotte refers to a place identified by Evans with Thicket, in Yorkshire. It has a Benedictine nunnery.

Toppolmo is Pegolotti's name for Tupholm, in Lincolnshire, the place of a Premonstratensian monastery. Pegolotti's Tornai (tornai in Italian is a verbal form for 'I returned') is Thorney, in Cambridgeshire, the place of a Benedictine monastery. Tornolmo is Pegolotti's name for Thornholm, in Lincolnshire, where there was an Austin Priory.

In Italian, the plural tresche denotes 'extramarital affairs'. Pegolotti however gave the name Tresche to Thirsk, in Yorkshire. Evans remarked: "An early variant of the name was Tresc. There was no monastery here; the church and some property were controlled by the Austin Priory of Newburgh (see Niuborgo). The town is listed as a center for 'collected wools', no doubt as representative of the North Riding (see Ledesia)".

La Trinitade di Londra is how Pegolotti refers to the Austin Priory of Holy Trinity in London. Remarkably, the name Uborno is the Italian adaptation of Woburn, in Bedforsdhire. It had a Cistercian monastery. By La Valdio, the Pratica della mercatura refers to Vaudey, in Lincolnshire, the place of Cistercian monastery. Vareale in Gualesi stands for Vale Royal in Wales, actually in Cheshire, where there was a Cistercian monastery.

We have already seen that Evans identifies Pegolotti's Vervicche with the city of 
York. S.v. Vervicche, Evans remarked: "Although strictly speaking it is a jurisdiction separate from all three Ridings, the town is perhaps here included as representative of the 'collected wools' of the East Riding (see Ledesia)". And finally, Pegolotti's Vicamo is Wykeham, in Yorkshire, where there was a Cistercian nunnery.

\section{Some data for comparison}

In the old toponomastics of England, one comes across many an example of adaptation to Old French, or to medieval Latin, even though in such Latin texts oftentimes there is no attempt to Latinise inserted place names. For example, in Cumbria, Geltsdale Forest is referred to around 1210 as forresta mea de Geltesdale ('my forest of Geltesdale'), and in 1609 as Foreste de Guiltesdale, but in 1610 as Forest of Gweltesdale (Armstrong et al. [1950] 1971:38).

Consider, in Cumbria, the old place name Liddesdale (Armstrong et al. [1950] 1971: 39). It is first recorded in the year 1165, in the partly Latinised form Vallis Lidel. In 1216, one finds valle de Lidel(le), and in 1359, valle de Ledalle. Forms with English dale occur as early as 1279, when Lidelesdal' is recorded. From 1307, there is the form Lyddsdale, but in 1388, Lydelysdale, and in 1470, Liddalisdale. It is as though there was an attempt to adapt the English genitive ending inside the compound, to how the Latin ending -is of a Latinised form (Liddalis) would be. In 1589, one comes across the form Lydderesdell.

One finds a Latin suffix added to the Germanic (English) name: in Staffordshire, the Cuttlestone Hundred is mentioned in 1086 in the Domesday Book in the forms Hundredum de Codwestan, Colvestan, Cudolvestan, Cudulvestan, or Culvestan (Oakden 1984: 24). In that area, Mitton was called Mutone in the Domesday Book (Oakden 1984: 86). In the Roman period, the nearby town of Penkridge was referred to, in the Antonine Itinerary, in the ablative as Pennocrucio, whereas there are many medieval forms of the place name, e.g., Pencris in 1203 (Oakden 1984: 87). Near Penkridge, Stretton is first mentioned in 1086 in the Domesday Book as Estretone, then between 1158 and 1165 one finds the forms Strettona and Stretunia, whereas the form Strattona occurs in 1175 and 1204. The etymological sense was 'the farmstead on the Roman road (Watling Street)' (Oakden 1984: 178). The town of Norbury (it, too, in the Cuttlestone Hundred) is first mentioned in 1086, in the Domesday Book, as Nortberie, whereas between 1316 and 1652 one also comes across the name type Nort(th)burgh for that same town (Oakden 1984: 173-174).

Gresopa and Cresope are forms, documented in 1165, of the name of the town of Kershope in Cumbria, now pronounced [ $\left.\mathrm{k}^{\boldsymbol{\nabla}} \mathrm{s} ə \mathrm{p}\right]$ or $\left[\mathrm{ka}^{\boldsymbol{\nabla}} \mathrm{s} ə \mathrm{p}\right]$ (Armstrong et al. [1950] 1971: 61). The name of the town of Cumwhitton, also in Cumbria, appears in various forms during the Middle Ages; one such form is Cumquetinton, recorded in 1288 (Armstrong et al. [1950] 1971: 78). Was there lexical interference from Latin cumque 'anyway'? "Occasionally there seems to be confusion of the forms for this name [Cumwhitton] and for the nearby Cumwhinton” (Armstrong et al. [1950] 1971: 78, fn. 1). 
The city of Exeter in Devon is referred to in Old French, around 1200, as la cite Dexcestre (Gover et al. 1969: 21). The name type Execester or Execestre occurs in the second half of the 11th century and in the 12th century. In 1086, one comes across the form Essecestra in the Exeter copy of the Domesday Book (Gover et al. 1969: 21).

Bittadon in Devon is referred to as Bedendona in the year 1086 in the Domesday Book (Gover et al. 1969: 29), and nearby Bratton Fleming (where Fleming is added to distinguish this town from Bratton Clovelly) appears in the Domesday Book as Bratona (Gover et al. 1969: 29-30). Nearby Benton appears in the Domesday Book as Bo(n)tintona (Gover et al. 1969: 30), and Haxton as Haustona (Gover et al. 1969: 31), whereas Braunton instead, also in Devon, appears in the Domesday Book as Branton (a) (Gover et al. 1969: 32). Nearby Ash Barton is mentioned as Essa in the Domesday Book (Gover et al. 1969: 32). Furze in Devon appears as Fersa in the Domesday Book (Gover et al. 1969: 35). Nearby Stoodleigh appears in 1086 as Estotleia in the Exeter copy of the Domesday Book, but as Stodlei in the Exchequer copy of the Domesday Book (Gover et al. 1969: 36).

The town of Churchill in Devon is first mentioned in the Domesday Book, as Cercilla, whereas it is mentioned in a document from France in 1121 as Cherchill (Gover et al. 1969: 38). This reminds me of an Italianised form of the surname of Winston Churchill, the diminutive Ciurcillino, which under the Fascist regime in Italy was given to a comics character intended to deride the British prime minister. In stories about him, Ciurcillino was always the loser. Children found Ciurcillino likeable, so the regime suppressed that comics character.

In Devon, the name of the town spelled as Woolfardisworthy is pronounced [wulsəri] or [ulsəri]. It is first mentioned in 1086, in the Domesday Book: in the Exeter copy as Olfereordi, and in the Exchequer copy as Olvereword. Nearby towns includes ones named Almiston [amsən] (Almerescota in the Domesday Book), and Ashmansworthy ['æ〔ənzəri], Essemundehorda in the Domesday Book (Gover et al. 1969: 80-81).

Again in Devon, there is the town of Okehampton. The locals pronounce its name as [okintən] or [okəntən] (Gover et al. 1969: 202). In the Domesday Book, it is mentioned as Ochenemitona; that was in 1086, but already around 970, the place was mentioned as (at) ocmund tune or (at) ocmond tune (Gover et al. 1969: 202). In 1222, the town is referred to as Ocumptona (Gover et al. 1969: 202). The town took its name from the river Okement.

The nearby hamlet of Chichacott [tisəkət] appears as Cicecota in 1086 in the Domesday Book, and, e.g., in 1549 as Chechecotte, with the folk-etymologising form Churchcott, whereas the place's name actually originated from a personal name, Cicca (Gover et al. 1969: 202), in the sense 'the cottage of Cicca'.

Near where I live, in the Bexley borough of London, Okehampton Crescent and Brampton Road meet at a roundabout. But local residents here pronounce the name Okehampton by keeping in pronunciation the $[\mathrm{h}]$ and the cluster $[\mathrm{mpt}]$. I remember that soon after in 1994 I moved into this house, I wrote a letter in Italian to my 
philosophy teacher from high school in Milan, and quipped that street names appeared to be Egyptianising, with a syncretistic bent: Ocantonio and Brampitone, the first clearly referring to L'Oca del Cairo ("The Goose from Cairo": Mozart's opera), which of course was Cleopatra (as being the oca 'goose' or 'foolish one', of Marcantonio, Mark Anthony). As for Brampitone, it is evidence, I claimed tongue in cheek, of some (Hellenistic or Roman-age) syncretism: Abramo 'Abraham' with Pitone 'Python'.

The standard British English idiom from Land's End to John o' Groats means 'throughout the island of Great Britain, from end to end': from Cornwall's westernmost tip, to Scotland's far end. Playfully years ago, in Italian I made up in the same sense da Bornamusa a Olifante, the two ends being Bournemouth on the Channel (by lexical interference from cornamusa 'pipes') to the territory of the Oliphant clan, near John o' Groats. Likewise, I once coined the phrase from Agadir to Anadir, for 'the Old World from end to end': from Morocco's Atlantic coast, to northeasternmost Siberia.

In the 1560 s, German miners were brought to the copper-rich Borrowdale area of Cumbria, and those miners gave Borrowdale a German name, Barnthal. They called Fornside Farenseit, Setmabanning Hiattmabainie, and Fawepark Vorbarckh (Armstrong et al. 1952: xxxix, fn. 1). "The Cumbrians had their revenge by turning the German surname Puchberger into Puphparker" (Armstrong et al. 1952: xxxix, fn. 1).

\section{Concluding remarks}

Pegolotti's Italianisations of a multitude of place names outside Italy is tantalising. In this article, we have rephrased and made available Pegolotti's names for places in England, Wales, and Scotland were there were monasteries, priories, or nunneries, as per a glossary by Allan Evans, included in the latter's 1936 edition of Pegolotti's La pratica della mercatura. The following (from http://numismatics.org/archives/ ark:/53695/nnan0158 - accessed in September 2017) is a biographical note about Allan Evans:

Allan Evans (1903-1970) was born in London, came to the United States in 1916, and was naturalized a U.S. citizen in 1939. He attended Harvard University (A.B., 1924; A.M., 1925; Ph.D., 1931) and remained there during the 1920s and 1930s as an instructor in German and history. He eventually left academia to work in U.S. intelligence in the State Department. In the 1930s, Evans worked on a project relating to medieval banking and exchange, organized by Harvard business historian Norman Gras and carried out under the auspices of the Mediaeval Academy of America, involving the analysis and publication of medieval merchant's notebooks, or manuals. Evans served as editor of one of the publications, La Practice della Mercatura (1936), focusing on the notebook of Francesco Balducci Pegolotti. Evans was also put in charge of another volume, which was originally conceived as a glossary of Italian coins, but as the project was carried forward became a more general work relating to the medieval accounting systems of merchants. Working with economic historian Florence Elder, the team began microfilming the unpublished merchant's notebooks, with portions intended for publication. The project was nearly completed in 1939, with publication set for 1940, but 
when Evans abandoned academic life for intelligence work, the project went uncompleted. The research materials passed to his assistant, Elder, whose husband, economic historian Raymond Adrien de Roover, made use of them in his own work.

\section{References}

Armstrong, A.M., A. Mawer, F.M. Stenton, and B. Dickins. 1950 (repr. 1971). The Place-Names of Cumberland. Part I: Eskdale, Cumberland and Leath Wards. (English Place-Name Society, 20.) Cambridge, England: Cambridge University Press.

Armstrong, A.M., A. Mawer, F.M. Stenton, and B. Dickins. 1952. The Place-Names of Cumberland. Part III: Introduction, etc. (English Place-Name Society, 22.) Cambridge, England: Cambridge University Press.

Battaglia, S. 1961-2002. Grande dizionario della lingua italiana, 21 vols. Torino: Unione Tipografico-Editrice Torinese. Completed under the direction of G. Bàrberi Squarotti, then followed by 2 supplements (ed. E. Sanguineti, 2004, 2009), + Index (ed. G. Ronco, 2004).

Bourquelot, F. 1865. Études sur les foires de Champagne, 2 vols. (Mémoires présentés par divers savants à l'Académie des Inscriptions et Belles Lettres, $2^{\mathrm{e}}$ série, Antiquités de la France, 5.) Paris: Imprimerie Impériale. Facsimile reprint, 2 vols., Brionne (France): Le Portulan, s.d. (1970).

Cordulack, S.W. 2003. Victorian Caricature and Classicism: Picturing the London Water Crisis. International Journal of the Classical Tradition 9(4): 535-583.

Cunningham, P. 1850. Hand-Book of London. Past and Present. A new edition corrected and enlarged. London: John Murray. [This is the edition cited. There also was a 4th ed., by Peter Cunningham (1816-1869), published around 1860; it was reprinted, Miami, Florida: Hardpress Publishing, 2012. The John Murray publishing house had later editions prepared by Henry Benjamin Wheatley (1838-1917), London, Past and Present: Its History, Associations, and Traditions, "three volumes extended to twelve by the addition of 780 extra illustrations”. Cunningham's version was not illustrated.]

Cunningham, W. 1910. Growth of English Industry and Commerce during the Early and Middle Ages, 5th ed. Cambridge: Cambridge University Press. [It also appeared as a Cambridge reprint in 1915 and 1927. There exists a reprint, London: Frank Cass, 1968. The first paperback edition was published by Cambridge University Press in 2011.]

Davidsohn, R. 1925. Geschichte von Florenz, Vol. 2. 3 vols. in 4 [history up to 1421], I: Ältere Geschichte, II: Guelfen und Ghibellinen (comprising: 1: Staufische kämpfe, 2: Die Guelfenherrschaft und der Sieg des Volkes), 3: Die letzten Kämpfe gegen die Reichsgewalt. Berlin: E.S. Mittler und Sohn, 1896-1927. Vols. 2 to 4 originally published with the title: Forschungen zur Geschichte von Florenz, 4 vols., 1896-1908. Also in Italian (but by Roberto instead of Robert Davidsohn): Storia di Firenze: le origini, 2 vols. (being a translation of Geschichte von Florenz, I: Ältere Geschichte), Firenze: G.C. Sansoni, 1907-1909. Also a revised Italian trans.: Storia di Firenze, traduzione italiana di Giovanni Battista Klein, riveduta da Roberto Palmarocchi, 8 vols., Firenze: Sansoni, 1977. German reprint: Forschungen zur älteren Geschichte von Florenz, 4 vols., Osnabrück: O. Zeller, 1973.

Espinas, G. 1923. La draperie dans la Flandre française au moyen-âge, 2 vols. Paris: A. Picard.

Germain, A. 1861. Histoire du commerce de Montpellier, 2 vols. Montpellier: Imprimerie de J. Martel aîné. 
Gover, J.E.B., A. Mawer, and F.M. Stenton. 1969. The Place-Names of Devon. Part I. (English Place-Name Society, 8.) Cambridge, England: Cambridge University Press.

Graesse, J.G.T. 1922. Orbis Latinus, oder, Verzeichnis der wichtigsten lateinischen Orts- und Ländernamen. Ein Supplement zu jedem lateinischen und geographischen Wörterbuch. Dritte Aufl., mit besonderer Berücksichtigung der mittelalterlichen und neueren Latinität neu bearbeitet von Friedrich Benedict. Berlin, 1922. Also, 4th ed.: Orbis Latinus: Lexikon lateinischer geographischer Namen des Mittelalters und der Neuzeit, [von Johann Georg Theodor] Graesse, [Friedrich] Benedict [und Helmut] Plecht; ... unter Mitarbeit von Günter Spitzbart. ("Handausgabe: Lateinisch-Deutsch, Deutsch-Lateinisch". Abbreviated version of "Grossausgabe" in 3 vols.), Braunschweig: Klinkhardt \& Biermann, [1971]. Also: J.G.T. Graesse, Orbis latinus, oder, Verzeichnis der lateinischen Benennungen der bekanntesten Städte etc., Meere Seen, Berge und Flüsse in allen Teilen der Erde, Amsterdam: B.R. Grüner 1969 (first published in Dresden, 1861). [A dictionary of medieval geography.]

Laufer, B. 1919. Sino-Iranica: Chinese Contributions to the History of Civilization in Ancient Iran. Publications of the Field Museum of Natural History. Anthropological Series, Vol. 15, No. 3, pp. i, iii-iv, 185-597, 599-630. Chicago, Illinois: Field Museum of Natural History. ${ }^{8}$

Nissan, E., and D. Burgaretta. Submitted. On the Italian Botanical Glosses in Version B of the Life of Ben Sira. [Over 110 pages.]

Oakden, J.P. 1984. The Place-Names of Staffordshire. Part I: Cuttlestone Hundred. (English Place-Name Society, 55.) English Place-Name Society [whose contact at the time was in Nottingham].

Pegolotti, F.B. [ca. 1335-1343] 1936 La pratica della mercatura, ed. A. Evans. (Mediaeval Academy Books, 24. $)^{9}$ Cambridge, Massachusetts: Mediaeval Academy of America. New York: Kraus Reprint, 1970. http://www.medievalacademy.org/resource/resmgr/maa_books_ online/evans_0024.htm (accessed in September 2017).

Reynolds, R.L. 1929. The Market for Northern Textiles in Genoa, 1179-1200. Revue Belge de Philologie et d'Histoire 8(3): 831-851.

Yule, H. (trans., ed.) 1913-1916. Cathay and the Way Thither: Being a Collection of Medieval Notices of China, $2 \mathrm{~d}$ ed., revised by H. Cordier, 4 vols. (Works issued by the Hakluyt Society, 2nd series, 33, 37-38, 41.) London: Hakluyt Society. The 1st ed. was 2 vols., 1866.

8 See http://www.jstor.org/stable/29782155 and http://openlibrary.org/b/ OL7045402M/Sino-Iranica (accessed in September 2017, accessible for free at both addresses).

9 http://www.medievalacademy.org/resource/resmgr/maa_books_online/ evans_0024.htm (accessed in September 2017). 